\title{
Thermal Expansion of Composite Resins and Sealants*
}

\author{
J. M. POWERS, R. W. HOSTETLER and J. B. DENNISON
}

School of Dentistry, University of Michigan, Ann Arbor, Michigan 48109

Linear thermal coefficients of expansion $(\alpha)$ of seven commercial composite resins and four pit and fissure sealants were determined between 0 and $60^{\circ} \mathrm{C}$ on a thermomechanical analyzer. The thermal expansion curves obtained were nonlinear. Values of $\alpha$ ranged from 26.5 to $39.6 \times 10^{-6}$ $\%$ for the composite and from 70.9 to $93.7 \times$ $10^{-6} 10 \mathrm{C}$ for the sealants.

J Dent Res 58(2):584-587, February 1979

\section{Introduction.}

Values of the linear thermal coefficient of expansion $(\alpha)$ of composite restorative materials have been reported by Macchi and Craig $^{1}$, and subsequently by Dennison and Craig $^{2}$, in their evaluations of physical and mechanical properties. In these studies, thermal dimensional change was determined on a specimen $(6.4 \mathrm{~mm}$ square and $51 \mathrm{~mm}$ long) between 24 and $88 \mathrm{C}$ with a method similar to that described in ASTM Specification D-696 for plastics. ${ }^{3}$ Values of $\alpha$, for composite resins available, ${ }^{1,2}$ ranged from 27 to $41 \times 10^{-6} /{ }^{\circ} \mathrm{C}$.

The purpose of this investigation was to determine the linear thermal coefficient of expansion of seven commercial composite resins and four pit and fissure sealants between 0 and $60^{\circ} \mathrm{C}$ from thermal expansion curves of specimens smaller than previously studied.

Received for publication February 28, 1978

Accepted for publication A pril 12, 1978

*This investigation was supported by Biomedical Research Support Grant RR-05321 from the National Institutes of Health, Bethesda, MD 20014.

The cooperation of the following companies in providing commercial products is acknowledged: L. D. Caulk Co., Johnson \& Johnson, Kerr Mfg. Co., 3M Co., and S. S. White.

This investigation was presented at the annual meeting of the International Association for Dental Research in Washington, D.C., March, 1978.

\section{Materials and methods.}

Seven commercial composite resins and four commercial pit and fissure sealants were evaluated for thermal expansion. Codes, batch numbers, and manufacturers of the products studied are listed in Table 1 .

Five cylindrical specimens $(3.7 \mathrm{~mm}$ in diameter and $7.7 \mathrm{~mm}$ long) were made for each product by polymerizing the resin in a metal die. The specimens were placed in an oven at $37^{\circ} \mathrm{C}$ within 90 seconds after initiating the mix, and were stored dry for 24 hours before testing. Specimens of the two materials activated by ultraviolet light (NF and NS) were polymerized in borosilicate glass tubing ( $3.50 \mathrm{~mm}$ inside diameter) by exposing the material to an ultraviolet light source* for a total of 20 minutes at a distance of $5 \mathrm{~cm}$.

Thermal expansion was measured by a commercial thermomechanical analyzer (TMA) $\uparrow$ at a heating rate of $5^{\circ} \mathrm{C} /$ minute. A quartz probe $(2.5 \mathrm{~mm}$ in diameter), which is attached to a metallic sleeve that serves as the core of a linear variable transformer (LVDT), was mechanically positioned by a spring on the surface of a specimen. The output of the LVDT was then balanced and zeroed electrically so subsequent vertical displacement could be calibrated and recorded as a function of temperature. A schematic sketch of the TMA cell has been shown previously. ${ }^{4}$ The probe was calibrated by measurement of the thermal expansion of an aluminum sample $\dagger$ with a linear coefficient of thermal expansion $(\alpha)$ of $23.2 \times 10^{-6} /{ }^{\circ} \mathrm{C}$ at a temperature of $27^{\circ} \mathrm{C}$. The mean calibration factor (S), determined from five replications, was $2.61 \mu \mathrm{m} / \mathrm{cm}$ of chart paper with a standard deviation of $0.05 \mu \mathrm{m} / \mathrm{cm}$. The linear coefficient of thermal expansion $(\alpha)$ was related

*Blak-Ray Model B-100A, Ultra-Violet Products, Inc., San Gabriel, CA 91775.

tduPont 941 Thermomechanical Analyzer, E. I. duPont de Nemours \& Co., Inc., Instrument Products Division, Wilmington, DE 19898. 
TABLE 1

CODE, BATCH NUMBERS AND MANUFACTURERS OF PRODUCTS TESTED.

\begin{tabular}{|c|c|c|c|}
\hline CODE & PRODUCT NAME & BATCH NUMBERS & MANUFACTURER \\
\hline \multicolumn{4}{|c|}{ Composite Resins: } \\
\hline A & Adaptic & $\begin{array}{l}\text { base-7E019 } \\
\text { catalyst-7E019 }\end{array}$ & $\begin{array}{l}\text { Johnson \& Johnson } \\
\text { Dental Products Division } \\
\text { East Windsor, NJ 08520 }\end{array}$ \\
\hline $\mathrm{AR}$ & Adaptic Radiopaque & $\begin{array}{l}\text { base-6L } 103 \\
\text { catalyst-6L103 }\end{array}$ & Johnson \& Johnson \\
\hline $\mathrm{C}$ & Concise & $\begin{array}{l}\text { base-7080E } 12 \\
\text { catalyst-7080E } 12\end{array}$ & $\begin{array}{l}\text { 3M Co. } \\
\text { St. Paul, MN } 55101\end{array}$ \\
\hline NF & Nuva-Fil & $\begin{array}{l}\text { base- }-052877 \\
\text { activator- } 120276\end{array}$ & $\begin{array}{l}\text { L. D. Caulk Co. } \\
\text { Division of Dentsply International, } \\
\text { Inc. Milford, DE } 19963\end{array}$ \\
\hline $\mathbf{P}$ & Powderlite & $\begin{array}{l}\text { powder-097702 } \\
\text { liquid-027612 }\end{array}$ & $\begin{array}{l}\text { S. S. White Division } \\
\text { Pennwalt Corporation } \\
\text { Philadelphia, PA } 19102\end{array}$ \\
\hline$S$ & Simulate & $\begin{array}{l}\text { base- } 0771061 \\
\text { catalyst-772096 }\end{array}$ & $\begin{array}{l}\text { Kerr Manufacturing Co. } \\
\text { Division of Sybron Corp. } \\
\text { Romulus, MI } 48174\end{array}$ \\
\hline $\mathrm{V}$ & Vytol & $\begin{array}{l}\text { base- } 042077 \\
\text { catalyst }-050477\end{array}$ & L. D. Caulk Co. \\
\hline \multicolumn{4}{|l|}{ Sealants: } \\
\hline $\mathrm{D}$ & Delton & $\begin{array}{l}\text { universal-1047D202 } \\
\text { catalyst-1047D202 }\end{array}$ & Johnson \& Johnson \\
\hline $\mathrm{K}$ & Kerr Sealant & $\begin{array}{l}\text { base- } 0513771083 \\
\text { catalyst }-0513771083\end{array}$ & Kerr Manufacturing Co. \\
\hline NS & Nuva-Seal & $\begin{array}{l}\text { base- } 040477 \\
\text { initiator- } 120276\end{array}$ & L. D. Caulk Co. \\
\hline W & White Sealant System & $\begin{array}{l}\text { resin } A-70702 \\
\text { resin B-7059B1 }\end{array}$ & $3 \mathrm{M} \mathrm{Co}$ \\
\hline
\end{tabular}

to the calibration factor (S) by the equation: $\mathrm{S}=\alpha \mathrm{h} /(\Delta \mathrm{l} / \Delta \mathrm{T})$, where $\mathrm{h}$ is the original height of the specimen and $(\Delta 1 / \Delta T)$ is the slope of the thermal expansion curve measured as the tangent to the curve at a given temperature, or determined as the straight line between two temperatures.

Thermal expansion curves were obtained over a temperature range of 0 to $60^{\circ} \mathrm{C}$ with the quartz probe applying a pressure of 2.0 $\mathrm{kPa}$ on dry specimens. To obtain a uniform heating rate initially, the specimens and test chamber were cooled to $-25^{\circ} \mathrm{C}$ by liquid nitrogen and then heated. Immediately after the first run had been made on a given specimen, the specimen was cooled to $-25^{\circ} \mathrm{C}$ and a second run was made. Data were analyzed statistically by a two-way analysis of variance 5 , and means were compared by Tukey's method ${ }^{6}$ at the 95 percent level of confidence.

\section{Results.}

Linear coefficients of thermal expansion $(\alpha)$ were calculated for three temperature ranges, 0 to $60^{\circ} \mathrm{C}, 10$ to $45^{\circ} \mathrm{C}$ and $37^{\circ} \mathrm{C}$. For the first two ranges, $\alpha$ was calculated by assuming $(\Delta 1 / \Delta \mathrm{T})$ in the aforementioned equation was a straight line between the two respective temperatures. The value of $\alpha$ at $37^{\circ} \mathrm{C}$ was calculated by equating the tangent of the thermal expansion curve at $37^{\circ} \mathrm{C}$ equal to $(\Delta 1 / \Delta \mathrm{T})$, where the tangent was determined graphically. Values of $\alpha$ determined for the aforementioned conditions are listed in Table 2 for runs 1 and 2 for the composites and sealants. Values of $\alpha$ for $P$ were obtained at powder/liquid ratios of $1 / 1$ and $1 / 2$ as indicated in Table 2.

Two-way analyses of variance were made for each temperature range separately for the composites and for the sealants to compare the effects of products and runs on $\alpha$. 
TABLE 2

LINEAR COEFFICIENTS OF THERMAL EXPANSION OF COMPOSITES AND SEALANTS FOR THREE TEMPERATURE RANGES.

\begin{tabular}{clccccr}
\hline & \multicolumn{6}{c}{ Linear Coefficient of Thermal Expansion*, $\times 10^{-6} /{ }^{\circ} \mathrm{C}$} \\
\cline { 2 - 7 } MATERIAL & \multicolumn{2}{c}{ 0 to $60^{\circ} \mathrm{C} \dagger$} & \multicolumn{2}{c}{10 to $45^{\circ} \mathrm{C}^{\ddagger}$} & \multicolumn{2}{c}{$37^{\circ} \mathrm{C} \S$} \\
\cline { 2 - 7 } & \multicolumn{1}{c}{ Run 1 } & Run 2 & Run 1 & Run 2 & Run 1 & Run 2 \\
\hline Composites: & & & & & \\
A & $40.1(1.2)$ & $35.8(0.7)$ & $40.0(1.5)$ & $34.2(0.5)$ & $49.8(1.7)$ & $39.4(0.7)$ \\
AR & $39.0(1.0)$ & $32.2(2.5)$ & $37.3(1.1)$ & $30.1(3.0)$ & $46.4(1.1)$ & $36.7(1.8)$ \\
C & $43.4(1.4)$ & $39.6(2.2)$ & $47.2(2.0)$ & $38.0(2.3)$ & $60.5(2.0)$ & $44.2(2.0)$ \\
NF & $30.2(2.4)$ & $28.3(1.3)$ & $28.2(2.3)$ & $27.5(1.4)$ & $31.7(1.8)$ & $30.6(1.0)$ \\
P(1/1) & $43.2(2.0)$ & $37.8(2.1)$ & $39.2(1.8)$ & $36.8(1.9)$ & $44.5(2.6)$ & $38.9(2.6)$ \\
P(1/2) & $53.0(2.1)$ & $47.3(1.5)$ & $51.6(1.7)$ & $46.2(1.2)$ & $60.9(2.2)$ & $51.7(1.7)$ \\
S & $31.6(2.4)$ & $28.2(1.3)$ & $31.6(1.5)$ & $26.6(1.2)$ & $41.6(1.7)$ & $32.0(1.7)$ \\
V & $27.8(1.7)$ & $26.5(1.6)$ & $27.0(1.9)$ & $24.9(2.1)$ & $35.1(1.9)$ & $30.3(1.3)$ \\
Sealants: & & & & & & \\
D & $97.1(1.8)$ & $90.3(1.2)$ & $93.5(1.6)$ & $88.9(1.4)$ & $103.5(2.0)$ & $96.1(1.2)$ \\
K & $78.2(4.2)$ & $70.9(3.9)$ & $76.5(4.7)$ & $68.5(3.6)$ & $90.9(6.1)$ & $79.0(4.7)$ \\
NS & $80(9)$ & $78(8)$ & $78(10)$ & $78(9)$ & $86(13)$ & $85(11)$ \\
W & $99.1(2.6)$ & $93.7(1.2)$ & $96.4(3.6)$ & $92.5(1.0)$ & $108.9(3.6)$ & $103.5(1.2)$ \\
\hline
\end{tabular}

*Mean value of five replications with standard deviations in parentheses.

$\dagger$ Tukey's intervals at the $95 \%$ level for comparisons among products and between runs were 2.5 and 0.8 for composites and 3.1 and 2.1 for sealants excluding NS.

$\$$ Tukey's intervals at the $95 \%$ level for comparisons among products between runs were 2.5 and 0.8 for composites and 3.3 and 2.2 for sealants excluding NS.

$\S$ Tukey's intervals at the $95 \%$ level for comparisons among products and between runs were 2.6 and 0.8 for composites and 4.0 and 2.7 for sealants excluding NS.

In each analysis, the effects of products, runs, and their interaction were significant statistically at the 95 percent level of confidence. Tukey's intervals for comparisons among means are listed in the footnotes of Table 2. The data for NS were not included in the analyses because the variance was unusually high.

Reheating of samples immediately after cooling from the first run resulted in changes in the thermal expansion curves as shown in Figure 1 for $\mathbf{P}(1 / 1)$. Subsequent reheating between 0 to $60^{\circ} \mathrm{C}$ produced no further changes in the thermal behavior. Values of $\alpha$ determined between 0 and $60^{\circ} \mathrm{C}$ were lower for run 2 than run 1 , the percent difference between them ( $\alpha$ run 2 - $\alpha$ run 1/ $\alpha$ run 1) being: A, $-10.7 ; \mathrm{AR},-17.4 ; \mathrm{C},-8.8$; $\mathrm{NF},-6.6 ; \mathrm{P}(1 / 1),-12.5 ; \mathrm{P}(1 / 2),-10.8$; $\mathrm{S},-10.8$; and $\mathrm{V},-4.7$ among the composites and $\mathrm{D},-7.0 ; \mathrm{K},-9.3 ; \mathrm{NS},-2.5$; and $\mathrm{W},-5.4$ among the sealants. The increased dimensional change associated with run 1 occurred at temperatures between 40 and $60^{\circ} \mathrm{C}$ for the composites and sealants tested.

Among the composite resins tested, the glass-filled materials (NF, S and $V$ ) had lower values of $\alpha\left(0\right.$ to $60^{\circ} \mathrm{C}$, run 2$)$, ranging from 26.5 to $28.2 \times 10^{-6} /{ }^{\circ} \mathrm{C}$, than the materials containing primarily quartz filler (A, AR, C, and $\mathrm{P}$ ) with values of $\alpha$ ranging from 32.2 to $43.7 \times 10^{-6} /{ }^{\circ} \mathrm{C}$. Among the sealants tested, $\alpha\left(0\right.$ to $60^{\circ} \mathrm{C}$, run 2$)$ varied from 70.9 to $93.7 \times 10^{-6} /{ }^{\circ} \mathrm{C}$. The quartzfilled sealant $(\mathrm{K})$ had lower values of $\alpha$ than the unfilled products. As a group, the sealants had much larger values of $\alpha$ than the composite resins.

\section{Discussion.}

The additional dimensional change associated with the thermal expansion curve of run 1 compared to run 2 between 40 and $60^{\circ}$ $C$ probably is caused by a release of residual compressive stress that is incorporated in the material during polymerization. The temperature at which this apparent release of stress begins is probably the glass transition temperature of the polymer phase of the materials tested.

Clinically, it is desirable for the thermal dimensional changes of restorative materials to approximate those of tooth structure to control marginal leakage and to maintain enamel bonding. The thermal coefficients of 


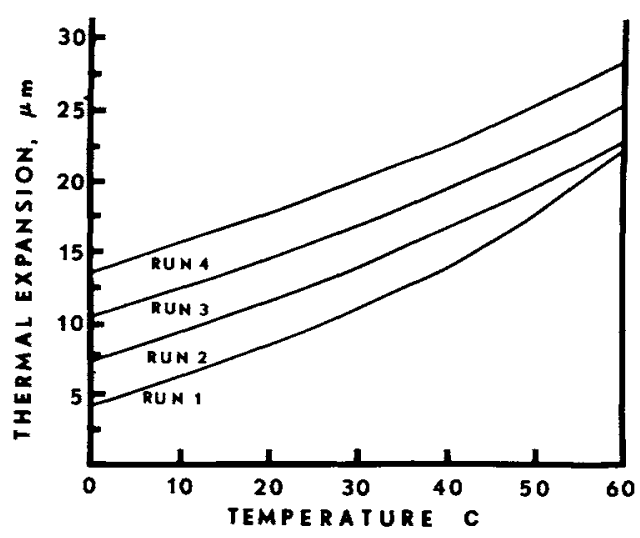

Fig. 1. - Thermal expansion curves for $P(1 / 1)$ showing differences in the dimensional change between the first run and subsequent runs. Curves are offset from each other for convenience.

expansion of the composites, and particularly the sealants, continue to be well above that of human tooth structure (about 11.4 $\left.\times 10^{-6} /{ }^{\circ} \mathrm{C}\right)^{7}$ The true clinical picture is quite complicated because thermal equilibrium is seldom obtained in the oral environment. The thermal diffusivity of composite resins $^{8}\left(0.675 \mathrm{~mm}^{2} / \mathrm{sec}\right)$ is greater than the values reported for either enamel $(0.469$ $\left.\mathrm{mm}^{2} / \mathrm{sec}\right)$ or dentin ${ }^{9}\left(0.183 \mathrm{~mm}^{2} / \mathrm{sec}\right)$. A thin coating of resin, as is utilized for sealing occlusal pits and fissures, has a greater potential for reaching thermal equilibrium than the bulk of material found in a restoration. The thinness of a coating does, however, help to minimize the actual dimensional change.

The effect of decreasing filler content to reduce viscosity in order to gain enamel bonding from a single mix of material can be observed by comparing $\mathrm{P}(1 / 1)$ and $\mathrm{P}(1 / 2)$. In decreasing the inorganic filler content 5 percent from 70.4 percent in $\mathrm{P}(1 / 1)$ to 65.8 percent in $\mathrm{P}(1 / 2)^{10}$, the linear coefficient of thermal expansion increased 25 percent from 37.8 to $47.3 \times 10^{-6} /{ }^{\circ} \mathrm{C}$ between 0 and $60^{\circ} \mathrm{C}$. There is, therefore, some indication that the thermal dimensional change should be less when a bonding agent is used with a viscous composite resin rather than a single mix resin-system with lower viscosity and decreased filler content.

\section{Conclusions.}

Linear thermal coefficients of expansion $(\alpha)$ of seven commercial composite restorative resins and four pit and fissure sealants were determined between 0 and $60^{\circ} \mathrm{C}$ on a thermomechanical analyzer. The thermal expansion curves obtained were nonlinear over this temperature range. Values of $\alpha$ determined upon reheating samples immediately after cooling from the first run decreased by as much as 17 percent. Upon reheating, values of $\alpha$ ranged from 26.5 to $39.9 \times 10^{-6} /{ }^{\circ} \mathrm{C}$ from the composites and from 70.9 to $93.7 \times 10^{-6} /{ }^{\circ} \mathrm{C}$ for the pit and fissure sealants between 0 and $60^{\circ} \mathrm{C}$. Composites with glass filler had lower values of $\alpha$ than ones with quartz filler.

\section{REFERENCES}

1. MACCHI, R. L.; and CRAIG, R. G.: Physical and mechanical properties of composite restorative materials, JADA 78:328-334, 1969.

2. DENNISON, J. B.: and CRAIG, R.G.: Physical properties and finished surface texture of composite restorative resins, JADA 85:101-108, 1972.

3. Standard method of test for coefficient of linear thermal expansion of plastics, D 69644, in ASTM Standards 1966, part 27, Philadelphia: American Society for Testing \& Materials, 1966, p. 256.

4. POWERS, J. M.; and CRAIG, R. G.: Penetration of commercial and dental waxes, $J$ Dent Res 53:402-409, 1974.

5. DALBY, JOHN, programmer: BMD8V-Analysis of variance, Ann Arbor, Statistical Research Laboratory, University of Michigan, 1968, 4 p.

6. GUENTHER, W. C.: Analysis of variance, Englewood Cliffs, NJ, Prentice-Hall, 1964, $199 \mathrm{p}$.

7. SAUDER, W. H.; and PAFFENBARGER, G. C.: Physical properties of dental materials, National Bureau of Standards Circular No. C433, Washington, D.C., 1942, U.S. Government Printing Office, $222 \mathrm{p}$.

8. CIVJAN, S.; BARONE, J. I.; REINKE, P. E.; and SELTING, W. J.: Thermal properties of nonmetallic restorative materials, $J$ Dent Res 51:1030-1037, 1972.

9. BROWN, W. S.; DEWEY, W. A.; and JACOBS, H. R.: Thermal properties of teeth, J Dent Res 49:752-755, 1970.

10. DENNISON, J. B.; and POWERS, J. M.: Unpublished data, University of Michigan, School of Dentistry, Ann Arbor, Michigan 48109 . 